\title{
Value Added Tax Administration and the Nigeria Economy
}

\author{
Dr.Sunday Aguwamba, Dr. Ughulu Stephen, Macaulay Onovughakpo Augustine
}

\begin{abstract}
The study is to investigates the impact of value added tax on revenue generation in Nigeria. The objective of the study is to assess the impact of value Added Tax in revenue generation of Nigeria. We source data from primary sources through oral interview and questionnaires distributed. The data were analysed with Simple percentages, bar charts, pie charts, and chi -square. The finding shows that: VAT has economic impact in consumption pattern in Nigeria; also VAT has positive impact on revenue generation in Nigeria. The payment of VAT has improved the prospects of businesses, organizations and industries in Nigeria and the study strongly recommends that: There should be functional VAT offices in every council area to coordinate a vigorous campaign to educate people and seek their cooperation. Finally, government should make adequate provision, for retrieving the VAT proceeds from companies and other collection agents.
\end{abstract}

Index Terms - Value added tax, Total Government Expenditure, Government Revenue, Unemployment and Inflation.

\section{INTRODUCTION}

Highlight The significant impact of VAT or the role played by Value added Tax in the development of the nation cannot be overemphasized. Revenue is raised by the government through taxation for the development of the nation. The pre-occupation of most countries in the world is to strive to achieve rapid overall development through optimum tax collection and expanded revenue base. In order to see that this very objective is accomplished, many countries in the world, especially developing countries, selectively introduced new forms of taxes to boost their revenue capacity with the aim of improving the socio-economic conditions of their citizens and achieving rapid economic development of the countries (Iorun, 2012). One of such forms of taxation is the Value Added Tax (VAT), this impressive performance of VAT virtually in all countries where it has been introduced clearly influenced the decision to introduce VAT in Nigeria in $1^{\text {st }}$ September, 1993, although actual operation did not begin until $1^{\text {st }}$ January 1994. VAT is a consumption tax that is relatively easy to administer and difficult to evade and it has been embraced by many countries of the world, (FIRS circular, 1999). Evidence so far support the view that VAT revenue is already a significant source of revenue in Nigeria and that the yield from VAT is a fairly accurate measurement of growth of an economy, since purchasing power which

Dr.Sunday Aguwamba, Department of Business Administration, Igbinadion University, Okada, Edo state, Nigeria

Dr, Ughulu Stephen, Department of Banking and Finance, Igbinadion University, Okada, Edo state, Nigeria

Macaulay Onovughakpo Augustine, Department of Business Administration, Igbinadion University, Okada, Edo state, Nigeria determine yield increases with the economy development.

According to Gupta, (2006), Value Added Tax (VAT) was introduced as a revenue mobilization strategy to cover up the deficiencies experienced with the former sales tax because of its progressive nature. Government ability to adequately and effectively retrieve the proceeds from companies and other agents of collection remains a problem. It does not appear as if there is adequate machinery for effectively monitoring of the remittance of the tax withheld to the relevant tax authorities, this means that the federal inland revenue, the body charged with the administration and implementation of VAT lacks the logistic support, this invariably will give room for tax evasion and avoidance.

The dishonest practice by some tax officials also posed a serious threat to effective tax administration in Nigeria, especially when such practices are capable of having demoralizing effects on the honest tax payers. Consumers will still want to low how much they are paying as VAT as most of these taxes are not duly reflected on their invoice. It is generally believed that VAT is another way of reflecting economic hardship on the consumer to the advantages of the manufacturers and companies. It could be seen as an excuse to raise prices of goods and services arbitrary. For instance, landlords are now charging VAT on house rents; some hotels are charging VAT on their services without remitting same to the appropriate authorities. These are contrary to the regulation governing the VAT system. Okpe, (2001).

The uncommon nature of this tax system (VAT), has resulted in unaware of its existence by majority with resultant effects of low credibility by the government, this has made people to scorn the payment. Lack of trained personnel and logistic support from the government and FIRS has contributed immensely to poor vat administration and implementation which invariably has resulted in reduction in revenue generation from VAT.

It is against these backdrops, this study seeks toascertain the effect of VAT on the Nigeria economy.

\section{RESEARCH OBJECTIVES}

The main objective of the study is to assess the impact of value Added Tax in revenue generation of Nigeria. Specifically, the study attempts to:

1. examine the effect of VAT on total government expenditure.

2. determine the impact of VAT on total government revenue.

3. Investigate the effect of VAT on unemployment.

4. examine whether VAT has significant effect on interest rate in the economy. 
5. examine the impact of VAT on inflation rate.

\section{Research Hypotheses}

The research hypotheses are stated in the null form. They are as follows:

1. ThatVAT does not significantly affect total government expenditure.

2. That VAT does not significantly affect total government revenue

3. That VAT does not significantly affect unemployment.

4. That VAT does not significantly interest rate in the economy.

5. That VAT does not significantly affect inflation rate.

\section{Methodology}

The research design is of a longitudinal research design and also causal research design since it involves finding the effect of one variable on another, and particularly how one variable cause one variable to change over time. The data for the study are sourced from the Central Bank of Nigerian (CBN) statistical bulletin and the reports of Federal Inland Revenue Service (FIRS) for various years.

\section{MODEL SPECIFICATION}

The model foe explaining the relationship between the dependent variable and the independent variable are status thus:

For the impact of VAT on total government expenditure:

$\mathrm{EXP}=\mathrm{f}(\mathrm{VAT}, \quad \mathrm{INT}, \quad$ INFR, MSP $)$ (3.1)

For the impact of VAT on total government revenue:

$\begin{array}{lll}\text { TRV } & \text { f(VAT, }\end{array}$

EXP)-

(3.2)

For the impact of VAT on unemployment:

UMP $\quad \mathrm{f}(\mathrm{VAT}, \quad \mathrm{INT}, \quad$ INFR, MSP)------------------------------------------------------ (3.3)

For the impact of VAT on interest rate:

INT $=\mathrm{f}(\mathrm{VAT}, \quad \mathrm{UMP}, \quad \mathrm{TRV}, \quad \mathrm{MSP}, \quad$ INFR, EXP)---------------------------------------- (3.4)

For the impact of VAT on inflation rate:

INFR = f(VAT, UMP, TRV, MSP,

EXP)

Where

$\mathrm{EXP}=$ total government expenditure

$\mathrm{VAT}=$ value added tax

INT $=$ interest rate

INFR $=$ inflation rate

MSP = money supply

TRV = total government revenue

$\mathrm{UMP}=$ unemployment rate

The models are stated econometrically as follows:

$$
\begin{gathered}
E X P_{t}=\alpha_{0}+\beta_{1} V A T_{t}+\beta_{2} I N T_{t}+\beta_{3} I N F R_{t}+\beta_{4} M S P_{t}+\varepsilon_{t} \\
T R V_{t}=\alpha_{0}+\beta_{1} V A T_{t}+\beta_{2} M S P_{t}+\beta_{3} E X P_{t}+\varepsilon_{t} \\
U M P_{t}=\alpha_{0}+\beta_{1} V A T_{t}+\beta_{2} I N T_{t}+\beta_{3} I N F R_{t}+\beta_{4} M S P_{t}+\varepsilon_{t} \\
I N T_{t}=\alpha_{0}+\beta_{1} V A T_{t}+\beta_{2} U M P_{t}+\beta_{3} T R V_{t}+\beta_{4} M S P_{t}+\beta_{5} I N F R_{t}+\beta_{6} E X P_{t}+\varepsilon_{t} \text { (3.9) } \\
I N F R_{t}=\propto_{0}+\beta_{1} V A T_{t}+\beta_{2} U M P_{t}+\beta_{3} T R V_{t}+\beta_{4} M S P_{t}+\beta_{5} E X P_{t}+\varepsilon_{t} \\
\text { The } \text { a priori expectations are as follows: } \\
\text { For model (3.6): } \propto_{0}>0, \beta_{1}>0, \beta_{2}>0, \beta_{3}<0, \beta_{4}>0 \\
\text { For model (3.7): } \propto_{0}>0, \beta_{1}>0, \beta_{2}>0, \beta_{3}>0 . \\
\text { For model (3.8): } \propto_{0}>0, \beta_{1}<0, \beta_{2}<0, \beta_{3}<0, \beta_{4}>0 . \\
\text { For model (3.9): } \propto_{0}>0, \beta_{1}>0, \beta_{2}<0, \beta_{3}<0, \beta_{4}<0, \beta_{5}>0, \beta_{6}>0 . \\
\text { For model (3.10): } \propto_{0}>0, \beta_{1}>0, \beta_{2}>0, \beta_{3}>0, \beta_{4}>0, \beta_{5}>0 .
\end{gathered}
$$

The results of the descriptive statistic as presented in table

The estimation methods used are descriptive statistic, correlation analysis and regression analysis.

\section{DATA ANALYSIS}

The estimation results are presented in this section. First among them is the descriptive statistic which is used to describe the distribution of the data with particular reference to normality of the data.
4.2.1 revealed that only INFL among the variables was found not to be statistically significant, hence not normally distributed. The other variables were found to be normally distributed using their Jarque-Bera statistic and the probability value of their Jarque-Bera statistic.

Table 4.2.1:Descriptive Statistic of the Data used for the study

\begin{tabular}{|l|c|c|c|c|c|c|c|}
\hline & VAT & UMP & TRV & MSP & INT & INFR & EXP01 \\
Mean & 136.0057 & 7.561905 & 1546.005 & 22186.26 & 18.33451 & 17.13836 & 1145.330 \\
Median & 87.44980 & 7.600000 & 1113.944 & 19436.78 & 17.98000 & 11.57798 & 1051.542 \\
Maximum & 389.5263 & 7.700000 & 3905.380 & 36707.33 & 24.85000 & 72.83550 & 3078.252 \\
Minimum & 5.026000 & 7.400000 & 49.50610 & 13046.30 & 13.54250 & 5.382224 & 160.8932 \\
Std. Dev. & 135.1863 & 0.074001 & 1412.054 & 8637.349 & 2.462622 & 16.92541 & 710.8383 \\
Skewness & 0.775056 & -0.040710 & 0.436309 & 0.468586 & 0.590928 & 2.432818 & 0.982231 \\
Kurtosis & 2.117823 & 2.718828 & 1.611667 & 1.640193 & 3.809699 & 7.837814 & 3.949730 \\
& & & & & & & \\
Jarque-Bera & 2.783449 & 0.074976 & 2.352814 & 2.386447 & 1.795849 & 41.19400 & 4.165962 \\
\hline
\end{tabular}


World Journal of Innovative Research (WJIR)

ISSN: 2454-8236, Volume-5, Issue-6, December 2018 Pages 47-52

\begin{tabular}{|l|l|l|l|l|l|l|l|}
\hline Probability & 0.248646 & 0.963206 & 0.308385 & 0.303242 & 0.407414 & 0.000000 & 0.124558 \\
& & & & & & & \\
Sum & 2856.120 & 158.8000 & 32466.10 & 465911.6 & 385.0247 & 359.9056 & 24051.93 \\
Sum Sq. Dev. & 365506.8 & 0.109524 & 39877929 & $1.49 \mathrm{E}+09$ & 121.2901 & 5729.393 & 10105821 \\
& & & & & & & \\
Observations & 21 & 21 & 21 & 21 & 21 & 21 \\
\hline
\end{tabular}

Source: Author's Estimation using EView, 2018.

The results of the correlation analysis shows that there is significant relationship between VAT and TRV, VAT and MSP are also found to be statistically significant. VAT and INT are also found to be significantly related with each other. But UMP, INFR and EXP were found not to have significant relationship with VAT. Some of the independent variables were also found to be significantly related while the others are not significantly related.

With majority of the independent variables not being significantly related, we can rely on the regression output for inferences as fear of the presence of serial correlation will be minimal. On the general ground, the correlation results show that VAT had considerable relationship variables of major concern in this study.

Table 4.2.2: Correlation Results of the Impact of VAT on Macroeconomic Variable

\begin{tabular}{|c|c|c|c|c|c|c|c|}
\hline $\begin{array}{l}\text { Correlation } \\
\text { Probability }\end{array}$ & VAT & UMP & TRV & MSP & INT & INFR & EXP \\
\hline VAT & $\begin{array}{l}1.000000 \\
---\end{array}$ & & & & & & \\
\hline UMP & $\begin{array}{l}0.014670 \\
0.9497\end{array}$ & $\begin{array}{l}1.000000 \\
-----\end{array}$ & & & & & \\
\hline TRV & $\begin{array}{l}0.980901 \\
0.0000\end{array}$ & $\begin{array}{l}0.111707 \\
0.6298\end{array}$ & $\begin{array}{l}1.000000 \\
----\end{array}$ & & & & \\
\hline MSP & $\begin{array}{l}0.983839 \\
0.0000\end{array}$ & $\begin{array}{l}0.065944 \\
0.7764\end{array}$ & $\begin{array}{l}0.992559 \\
0.0000\end{array}$ & $\begin{array}{l}1.000000 \\
----\end{array}$ & & & \\
\hline INT & $\begin{array}{l}-0.454484 \\
0.0385\end{array}$ & $\begin{array}{l}0.152948 \\
0.5080\end{array}$ & $\begin{array}{l}-0.485992 \\
0.0255\end{array}$ & $\begin{array}{l}-0.471337 \\
0.0310\end{array}$ & $\begin{array}{l}1.000000 \\
----\end{array}$ & & \\
\hline INFR & $\begin{array}{l}-0.376595 \\
0.0924\end{array}$ & $\begin{array}{l}-0.419482 \\
0.0584\end{array}$ & $\begin{array}{l}-0.401932 \\
0.0709\end{array}$ & $\begin{array}{l}-0.364349 \\
0.1044\end{array}$ & $\begin{array}{l}0.356963 \\
0.1122\end{array}$ & $\begin{array}{l}1.000000 \\
----\end{array}$ & \\
\hline EXP & $\begin{array}{l}0.327338 \\
0.1475\end{array}$ & $\begin{array}{l}0.531481 \\
0.0132\end{array}$ & $\begin{array}{l}0.484060 \\
0.0262\end{array}$ & $\begin{array}{l}0.430011 \\
0.0517\end{array}$ & $\begin{array}{l}-0.324029 \\
0.1519\end{array}$ & $\begin{array}{l}-0.470005 \\
0.0316\end{array}$ & $\begin{array}{l}1.000000 \\
----\end{array}$ \\
\hline
\end{tabular}

Source: Author's Estimation using EView, 2018.

Table 4.2.3: Regression Results of the Impact of VAT on Total Government $\quad$ Expenditure

\begin{tabular}{llcccc}
\hline \hline \multirow{2}{*}{ Dependent Variable } & Independent Variable & Coefficient & Std. Error & t-Statistic & Prob. \\
\hline \hline \multirow{2}{*}{ EXP } & C & -2432.547 & 1485.256 & -1.637797 & 0.1210 \\
& VAT & -16.93925 & 4.518191 & -3.749123 & 0.0018 \\
& INT & -4.768396 & 51.37927 & -0.092808 & 0.9272 \\
& INFR & -17.85451 & 7.109831 & -2.511243 & 0.0231 \\
& MSP & 0.282839 & 0.071053 & 3.980676 & 0.0011 \\
\hline \hline & R-squared & 0.628493 & Mean dependent var & 1145.330 \\
& Adjusted R-squared & 0.535616 & S.D. dependent var & 710.8383 \\
S.E. of regression & 484.4058 & Akaike info criterion & 15.40798 \\
& Sum squared resid & 3754384. & Schwarz criterion & 15.65668 \\
& Log likelihood & -156.7838 & Hannan-Quinn criter. & 15.46195 \\
F-statistic & 6.766955 & Durbin-Watson stat & 1.879528 \\
& Prob(F-statistic) & 0.002187 & & & \\
\hline \hline
\end{tabular}

Source: Author's Estimation using EView, 2018.

The regression results in table 4.2.3 revealed that VAT significantly affects EXP. This is shown by the t-value of -3.749123 with a probability value of 0.0018 which is significant at $5 \%$ level of statistical significance. A unit change in VAT will lead to $169.3925 \%$ change in total government expenditure. The coefficient of determination for the model shows that the independent variable accounts for $62.8493 \%$ in the systematic variation of the dependent variable. The Adjusted coefficient of determination shows that the model is properly fitted in describing the hypothesized relationship. The F-statistic value of 
6.7669 and the probability value of 0.002187 revealed that on the overall, the model is statistically significant in proving the explanation between the variables. The Durbin - Watson statistic of 1.879528 shows that there is no serial correlation in the model used, hence the reliance on the regression results for inferences. Below is the mathematical representation of the regression model.

$\mathrm{EXP}=-2432.54739391-16.9392541746 * \mathrm{VAT}-4.76839565924 * \mathrm{INT}-$

$17.8545125988 *$ INFR $+0.282838787949 *$ MSP

The signs as shown in the equation above revealed that VAT negatively affect total government expenditure. This implied that the higher the values of VAT, the more the government is likely to spend. This is so, because government expenditure involves the purchase of goods and payment for service (consumption) in the domestic economy which involves the payment of VAT.

Table 4.2.4: Regression Results of the Impact of VAT on Total Government $\quad$ Revenue

\begin{tabular}{llcccc}
\hline \hline \multirow{2}{*}{ Dependent Variable } & Independent Variable & Coefficient & Std. Error & t-Statistic & Prob. \\
\hline \hline \multirow{2}{*}{ TRV } & C & -1478.947 & 153.9943 & -9.603905 & 0.0000 \\
& VAT & $1.27 \mathrm{E}-06$ & $2.81 \mathrm{E}-07$ & 4.515401 & 0.0003 \\
& MSP & 0.108408 & 0.011263 & 9.625176 & 0.0000 \\
& EXP & 0.308122 & 0.052853 & 5.829837 & 0.0000 \\
\hline \hline & R-squared & 0.995087 & Mean dependent var & 1546.005 \\
& Adjusted R-squared & 0.994220 & S.D. dependent var & 1412.054 \\
S.E. of regression & 107.3569 & Akaike info criterion & 12.35984 \\
& Sum squared resid & 195933.5 & Schwarz criterion & 12.55879 \\
& Log likelihood & -125.7783 & Hannan-Quinn criter. & 12.40302 \\
& F-statistic & 1147.658 & Durbin-Watson stat & 1.979043 \\
Prob(F-statistic) & 0.000000 & & \\
\hline \hline
\end{tabular}

Source: Author's Estimation using EView, 2018.

The regression result presented in table 4.2.4 revealed that total government expenditure is significantly affected by VAT. This is shown by a t-value of 4.515401 and a probability value of 0.0003 . The R- squared value of 99.5087 revealed to the extent that the independent variable account for the systematic variation in the dependent variable. And also the model of goodness of fit revealed that the model is properly fitted. The F-statistic value of 1147.658 with a probability value of 0.0000 revealed that on the overall, the model is properly fitted. The Durbin - Watson statistic revealed that there is no presence of serial correlation in the model. Below is the mathematical representation of the model showing signs and magnitudes.

$\mathrm{TRV}=-1478.94695903+1.26659539565 \mathrm{E}-06 * \mathrm{VAT}+0.108408001495 * \mathrm{MSP}$ $+0.308122321955^{*} \mathrm{EXP}$

The sign of the independent variable revealed that VAT has positive impact on Total Government Revenue. This shows that the higher the VAT the higher will be the total revenue collected by the government.

Table 4.2.5: Regression Results of the Impact of VAT on Unemployment

\begin{tabular}{|c|c|c|c|c|c|c|}
\hline Dependent Variable: & Independent Variable & Coefficient & Std. Error & $\mathrm{t}$-Statistic & & Prob. \\
\hline \multirow[t]{15}{*}{ UMP } & $\mathrm{C}$ & 7.151292 & 0.194937 & 36.68517 & & 0.0000 \\
\hline & VAT & -0.001101 & 0.000593 & -1.856418 & & 0.0819 \\
\hline & INT & 0.012001 & 0.006743 & 1.779714 & & 0.0941 \\
\hline & INFR & -0.002550 & 0.000933 & -2.733198 & & 0.0147 \\
\hline & MSP & $1.73 \mathrm{E}-05$ & $9.33 \mathrm{E}-06$ & 1.856014 & & 0.0820 \\
\hline & R-squared & 0.409505 & \multirow{3}{*}{\multicolumn{2}{|c|}{$\begin{array}{l}\text { Mean dependent var } \\
\text { S.D. dependent var }\end{array}$}} & & 7.561905 \\
\hline & Adjusted R-squared & 0.261881 & & & & 0.074001 \\
\hline & & & & & & -2.46886 \\
\hline & S.E. of regression & 0.063577 & \multirow{2}{*}{\multicolumn{2}{|c|}{ Akaike info criterion }} & 4 & \\
\hline & & & & & & -2.22016 \\
\hline & Sum squared resid & 0.064673 & \multirow{2}{*}{\multicolumn{2}{|c|}{ Schwarz criterion }} & 8 & \\
\hline & & & & & & -2.41489 \\
\hline & Log likelihood & 30.92307 & \multirow{3}{*}{\multicolumn{2}{|c|}{$\begin{array}{l}\text { Hannan-Quinn criter. } \\
\text { Durbin-Watson stat }\end{array}$}} & 0 & \\
\hline & F-statistic & 2.773973 & & & & 1.748378 \\
\hline & Prob(F-statistic) & 0.063208 & & & & \\
\hline
\end{tabular}

Source: Author's Estimation using EView, 2018. 
The regression results of the model for the impact of VAT on UMP shows that VAT does not significantly affect unemployment. This is shown by a t-value of -1.856418 with a probability value of 0.0819 . The Durbin-Watson statistic in the model shows that there is no serial correlation. Below is the mathematical representation of the model.

$\mathrm{UMP}=7.15129203405-0.00110086253488 * \mathrm{VAT}+0.0120013741741 * \mathrm{INT}-$

$0.00255048705577 * \mathrm{INFR}+1.73083722688 \mathrm{E}-05 * \mathrm{MSP}$

The equation of the model revealed that VAT has a negative relationship with VAT. This could be that the higher the VAT raised by the government the more enabled the government will be in generating employment opportunities and therefore reducing unemployment in the economy.

Table 4.2.6: Regression Results of the Impact of VAT on Interest Rate

\begin{tabular}{llllll}
\hline \hline \multirow{2}{*}{ Dependent Variable } & Variable & Coefficient & Std. Error & t-Statistic & Prob. \\
\hline \hline \multirow{2}{*}{ INT } & C & -119.0468 & 74.87132 & -1.590019 & 0.1342 \\
& VAT & $4.28 \mathrm{E}-09$ & $9.69 \mathrm{E}-09$ & 0.441427 & 0.6656 \\
& UMP & 17.77925 & 9.521819 & 1.867211 & 0.0830 \\
& TRV & -0.003453 & 0.005580 & -0.618853 & 0.5460 \\
& MSP & 0.000309 & 0.000638 & 0.485221 & 0.6350 \\
& INFR & 0.043646 & 0.036313 & 1.201919 & 0.2493 \\
& EXP & -0.000208 & 0.001943 & -0.106846 & 0.9164 \\
\hline \hline & R-squared & 0.421331 & Mean dependent var & 18.33451 \\
& Adjusted R-squared & 0.173330 & S.D. dependent var & 2.462622 \\
& S.E. of regression & 2.239050 & Akaike info criterion & 4.711182 \\
& Sum squared resid & 70.18680 & Schwarz criterion & 5.059356 \\
& Log likelihood & -42.46741 & Hannan-Quinn criter. & 4.786744 \\
& F-statistic & 1.698910 & Durbin-Watson stat & 2.133354 \\
& Prob(F-statistic) & 0.193807 & & & \\
\hline \hline
\end{tabular}

Source: Author's Estimation using EView, 2018.

The regression result in table 4.2.6 revealed that interest rate is not significantly affected by VAT. This is shown by a t-value of 1.867211 with a probability value of 0.0830 . Below is the mathematical representation of the model.

$\mathrm{INT}=4.2773342159 \mathrm{E}-09 * \mathrm{VAT}+17.7792489383 * \mathrm{UMP}-$

$0.0034531746337 * \mathrm{TRV}+0.000309355460483 * \mathrm{MSP}+0.043645546737 * \mathrm{INFR}-0.000207605796632 * \mathrm{EXP} 01-$ 119.046796233

Table 4.2.7: Regression Results of the Impact of VAT on Inflation Rate

\begin{tabular}{lllccc}
\hline \hline \multirow{2}{*}{ Dependent Variable: } & Variable & Coefficient & Std. Error & t-Statistic & Prob. \\
\hline \hline \multirow{2}{*}{ INFR } & C & 525.9283 & 514.7493 & 1.021717 & 0.3231 \\
& VAT & $-1.56 \mathrm{E}-08$ & $6.88 \mathrm{E}-08$ & -0.227303 & 0.8233 \\
& UMP & -68.85551 & 65.32732 & -1.054008 & 0.3086 \\
TRV & -0.009908 & 0.039593 & -0.250252 & 0.8058 \\
MSP & 0.001655 & 0.004513 & 0.366700 & 0.7190 \\
& EXP01 & -0.005427 & 0.013744 & -0.394856 & 0.6985 \\
\hline \hline & R-squared & 0.336426 & Mean dependent var & 17.13836 \\
& Adjusted R-squared & 0.115235 & S.D. dependent var & 16.92541 \\
& S.E. of regression & 15.92038 & Akaike info criterion & 8.608033 \\
& Sum squared resid & 3801.876 & Schwarz criterion & 8.906468 \\
& Log likelihood & -84.38435 & Hannan-Quinn criter. & 8.672801 \\
& F-statistic & 1.520973 & Durbin-Watson stat & 1.083580 \\
& Prob(F-statistic) & 0.241977 & & & \\
\hline \hline
\end{tabular}

Source: Author's Estimation using EView, 2018.

The regression result revealed that VAT does not significantly affect the rate of inflation in the economy.

Following from the empirical analysis of the data set, we interpret the results of the hypotheses as follows:

For hypotheses one, we reject the null hypotheses that
VAT does not significantly affect total government expenditure. (see table 4.2.3)

For hypotheses two, we reject the null hypotheses and accept the alternative hypotheses that total government revenue is significantly affected by total government revenue 
(see table 4.2.4).

For hypotheses three, we accept the null hypothesis that VAT does not significantly affect unemployment in the Nigerian economy (see table 4.2.5).

For hypothesis four, we accept the null hypothesis that VAT does not significantly affect interest rate in Nigerian economy (see table 4.2.6).

For hypothesis five, we accept the null hypothesis that VAT does not significantly affect inflation Nigerian economy (see table 4.2.7).

\section{SUMMARY OF FINDINGS}

The findings from the empirical analysis of the data are summarized below:

1. That value added tax significantly but negatively affects total government expenditure.

2. That value added tax significantly and positively affects total government revenue

3. That value added tax does not significantly affect unemployment rate in the Nigerian economy.

4. That value added tax does not significantly affect interest rate in the Nigerian economy.

5. That value added tax does not significantly affect the rate of inflation in the Nigerian economy.

\section{CONCLUSION}

Based on the empirical findings from the data analysis we therefore conclude that value added tax is a major source of revenue for the government, however, it is also a major point of concern for the government as it affect expenditure adversely in the economy.

\section{REFERENCES}

[1] Adams, S. (1910) The Wealth of Nations; London; Everyman's Library Ltd.

[2] Adefila, J.J. (2008) Research Methodology in Behavioural Sciences, Kaduna, Nigeria; Apani Publications.

[3] Adereti S.A., Sanni M.R. and Adesina J.A. (2011) Value Added Tax and Economic Growth of Nigeria, EuropeanJournal of Humanities and Social Science 10(1) special issue

[4] Aguolu O. (1999) Taxation and Tax Management in Nigeria, Enugu, Meridian Associates.

[5] Aguolu,O. (2004) Taxation and Tax Management in Nigeria, 3rd Edition, Enugu; Meridan Associates.

[6] Ajakaiye D.O. (2000) Macroeconomic Effects of VAT in Nigeria: A Computable General Equilibrium Analysis,African Economic Research Consortium (AERC) Paper No 92

[7] Alugbo C. C. (2002) A practical guide to project writing credo publications owerri, Imo estate.

[8] Alugbo, C. C. (2005). A practical guide to project writing. Credo publication, OwerriImo State Nigeria.

[9] Asika N. (2006) Research Methodology in the Behaviour Sciences.Longman Nigeria Plc, Ikeja Lagos.

[10] Balls,O. (1965) The Problems of Tax Administration. In Latin America, Baltimore; John Hopkins Press.

[11] Baridan, D. M. (2001) Research Method in Administrative Science.2nd edition, road Port Harcourt, Shevr Books Associates.

[12] Chima, B. 0.andUdensi C. E. (1996) Government \& Business Relations. The Nigeria Perspective Precision Printers and Publishers, Achara Layout, Enugu.

[13] Clifford, J. C. (1965) -VAT, the British System Explainedll pp. 44-47 London Pitman.

[14] DangnhaKoti - (2007) - Indirect Taxationll. Saleua Press. Evidence Publishers Enugu, Nigeria.

[15] Ekeocha P.C (2010) Modelling the Potential Economic Effects of VAT Reform: Simulation Analysis using Computable General Equilibrium Analysis, paper submitted for ECOMOD, Istanbul Turkey, July 7.

[16] Ezejelue A. C. (2001) Primer on International Accounting.Educational Books and Investment Limited. Port Harcourt - Rivers State.
[17] Farayola, G.O. (1987) Guide to Nigerian Taxation, Ikeja, All Group Nigeria Limited Publishers.

[18] Gupta, R. N. (2006) Business Organization and Management. Rain Nager, New Delhi Management

[19] Musgrave, R.A and Peacock, A.I (1984) Classics in the Theory of Public Finance, New York; Macmillan.

[20] Naiyeju, K. (1996) Value Added Tax, the facts of a positive Tax in Nigeria.1st Edo.KUPAG Public Affairs, pp. 97.

[21] Nwabuokei P. 0. (1986): Fundamental of statistics. chumezNigeria enterprises, Agbani Road, Enugu.

[22] Obi, I. J. (1993) Policy and Administration of Value Added Tax' in Nigeria 3rd Edition.Ochhiogu Publishers

[23] Okafor, U. S. (1996) Marketing Research and Project Writing guide World Communication Ltd. Ikeja Lagos.

[24] Okpe, T. J. (2001) Guide to Nigerian Companies Taxation, Enugu. Chiezugo Ventures.

[25] Ola, C. S. (1999) Nigeria Income TAX and Practice. Heinem an Educational Books Nigeria Plc, Ibadan.

[26] Onodugo V. A. Ugwuonah G. E. and Ebbinne E. S. (2010) Social Science Research, Principles, Methods and Applications.El-Demark Publishers Enugu.

[27] Owolabi S.A. and Okwu A.T. (2011) Empirical Evaluation of Contribution of Value Added Tax (VAT) to Development of Lagos State Economy Middle Eastern Finance and Economics, Euro Journals Publishing

[28] Osisoma, B. C. (1990) Studies in Accountancy, Texts and Readings Enugu.New age Publishers.

[29] Oyegbile S. 0. (1996) The Principle and practice of Property Rating and Taxation. Jamesons Graphic Publishers

[30] Seyi, 0.(1993) Fundamental Principles of Nigeria Tax.Sagriba Tax Publication. VAT Decree 1993 - First circular No. 9304. 1MF Report.

[31] Sommefeld, R.M.(1980) An Introduction to Taxation, Harcourt Brace, Jovanovich.

[32] Soyode, L. and Kajola, S.O (2006) Taxation Principals and Practice in Nigeria, Ibadan, Nigeria; Solicon Publishers.

[33] Surrey, S.S (1965) Tax Administration In Under Developing Countries, Baltimore; John Hopkins Press.

[34] Yamane and Yaro (1967) Statistics: An Introductory Analysis, 2nd Edition, New York; Harper and Row. 